\title{
Towards quantitative palynology: using pollen accumulation rates and models of pollen dispersal
}

\author{
Thomas Giesecke $\cdot$ Willem O. van der Knaap • \\ Felix Bittmann
}

Received: 7 June 2010/Accepted: 8 June 2010

(C) The Author(s) 2010. This article is published with open access at Springerlink.com

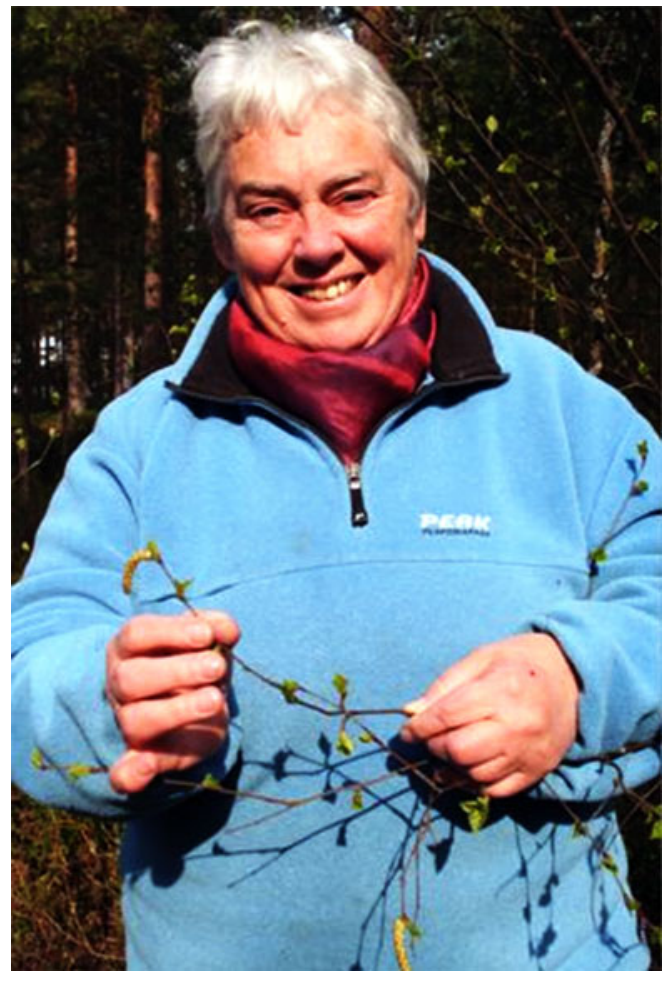

T. Giesecke $(\bowtie)$

Albrecht-von-Haller-Institute for Plant Sciences, Department of Palynology and Climate Dynamics, University of Göttingen, Untere Karspüle 2, 37073 Göttingen, Germany

e-mail: Thomas.Giesecke@ biologie.uni-goettingen.de

W. O. van der Knaap

Institute of Plant Sciences and Oeschger Centre for Climate Change Research, University of Bern, Altenbergrain 21, 3013 Bern, Switzerland

\section{F. Bittmann}

Lower Saxony Institute for Historical Coastal Research, Viktoriastr. 26/28, 26382 Wilhelmshaven, Germany
The name Sheila Hicks is for many palaeoecologists connected with pollen trapping and absolute pollen deposition, and it is therefore an enormous pleasure to dedicate this special issue of Vegetation History and Archaeobotany to Sheila Hicks on the occasion of her retirement from Oulu University. Over the years Sheila's enthusiasm for pollen trapping has inspired many graduate students as well as junior and senior colleagues and friends. Sheila started trapping pollen in Finland in 1969 (Hicks 1974), at a time when much of the early pioneering work on the modes of pollen dispersal and deposition was carried out. She experimented with pollen traps in the field (Hicks and Hyvärinen 1986) and established monitoring stations in different vegetation zones of Finland, where through perseverance she has collected continuous time series, which stand as an invaluable resource for generations to come. During the late 1970s and 1980s, the early hope to use absolute pollen deposition as a means of quantitative reconstruction of vegetation change declined due to the many problems of sedimentary environments (Davis 2000). Despite this declining interest in the subject, Sheila continued her work and convinced many students and colleagues of the value of absolute pollen deposition in pollen traps and sediment cores, which led to a renewed interest in absolute pollen deposition in recent years (Barnekow et al. 2008; Gerasimidis et al. 2008; Giesecke and Fontana 2008; Sjögren et al. 2008; Kuoppamaa et al. 2009; Huusko and Hicks 2009).

With the support of colleagues, Sheila created the Pollen Monitoring Programme (PMP) as an INQUA working group with the aim to standardize pollen monitoring and accumulate a large body of data that could be used to interpret fossil pollen assemblages (Hicks 2001). Three contributions in this special volume are based on the large dataset that is being collected within the programme and thus testify to the 
success of this network. Sheila Hicks has served as a president for the PMP for more than ten years and thereafter stayed on supporting the programme, whose regular international workshops have facilitated the interaction of many scientists, especially from East European countries.

Through comparisons between the pollen producing vegetation and pollen spectra in traps and surface samples Sheila gained insights into modes of pollen transport and deposition, which have benefitted the POLLANDCAL network (Gaillard et al. 2008). In turn the advances in dispersal theory have been fruitful in the work with pollen trapping results (Poska and Pidek 2010; Sugita et al. 2009). Thus by keeping faith in the usefulness of absolute pollen deposition and bringing it together with new theoretical developments in pollen dispersal and deposition, Sheila has made a major contribution to the methodological developments in late Quaternary palynology. In tribute to her activities, colleagues and friends have brought together a number of articles in this special volume on these two themes of pollen trapping and quantitative reconstructions using models of pollen dispersal and deposition.

The decision to focus on the above topics for this special volume was made in the hope of producing a coherent topical volume, but we do not overlook Sheila's other interests and contributions, among which her cooperation with dendrologists should be highlighted. Pollen trapping allows insights into the inter-annual variability in pollen production and thus lends itself to comparisons with interannual variations in tree growth (McCarroll et al. 2003). Utilizing this concept Sheila led several EU funded research projects together with dendrologists focusing on the influence of temperature on tree growth and pollen production (Hicks 1999; Autio and Hicks 2004). This interaction, her experience in working with a high time resolution, wide interest and superb skills in working with people make her an excellent coordinator and human resource manager of the European Climate of the Last Millennium project which brings together more than 38 partners from 16 European countries.

Worth mentioning are also Sheila's efforts to serve the scientific community with her commitment to the European Pollen Database (EPD) where she served for many years as the chair of the advisory board (Fyfe et al. 2009). Inspired by the usefulness of databases Sheila has initiated a database for pollen trapping results, which serves as a research tool for the PMP.

The articles in this special issue are following a similar series as Sheila's research, from pollen trapping to quantitative reconstructions, starting with a historical introduction to pollen trapping as well as an overview of current activities (Giesecke et al.). While setting the scene for the following contributions on pollen trapping, this essay also introduces the PMP study sites that provided the data for the following three contributions. The first of these looks at the inter-annual variability of Fagus pollen deposition across Europe as well as the relationship between the regional abundance of Fagus and the average absolute deposition of Fagus pollen in the traps (Pidek et al.). The latter clearly highlights the long proposed linear relationship between plant abundance and pollen deposition (Davis 2000). Following the ideas developed by Sheila and coworkers (Räsänen et al. 2004) the second of these three contributions investigates the differences between pollen spectra in pollen traps versus those in adjacent moss samples (Pardoe et al.). This analysis indicates that there may be a systematic bias between the two trapping media. It also shows that the pollen spectra from moss samples mostly represent the pollen deposition of several years, especially if the samples include the brown dead part of the moss. The third contribution based on the PMP dataset investigated if and how the inter-annual temperature and precipitation variability influences the production and dispersal of pollen for all common pollen types in the different regions (van der Knaap et al.). Several pollen types yielded roughly similar results for different regions, for example warm summers were found to favour Picea pollen production in the following year. However, regional differences were visible in the variability of pollen deposition and possible influencing of climate variables for many pollen types. The contribution by Nielsen et al. is based on the long pollen trapping dataset initiated by Svend Th. Andersen in 1967 in Draved forest, Denmark. This dataset shows, for example, that the biannual flowering of Betula observed by Andersen (1980) is not apparent in the later years. Its analysis using regression models with multiple climate variables as predictors indicates that a large proportion of the variability in pollen deposition can be explained for some taxa, while poor or no relationships exist for others. In the analysis of the PMP dataset as well as of the long series from Draved forest it becomes apparent that most individual trees have inherent cycles in flowering variability and seed production which are brought into tune by the inter-annual variations in temperature and precipitation. Following the long-term monitoring dataset the contribution by Birks and Bjune present a well designed pollen and macrofossil trapping experiment studying the pollen accumulation rates across an altitudinal tree-line. Especially interesting here is the combination of pollen accumulation rates and the trapping of macroscopic plant remains as well as the combination of traps on land with traps in a small lake. This contribution shows that pollen accumulation rates in mountainous areas may not be sensitive to the position of the tree-line and that lakes receiving pollen with surface runoff can yield spurious pollen accumulation rates. The contribution by Sjögren et al. builds the bridge from 
pollen trapping to quantitative reconstructions using models of pollen dispersal, and shows that it can be advantageous to combine different pollen dispersal functions. This concept is then applied to pollen traps from Bulgaria and Georgia to estimate absolute pollen productivity of Tertiary relict taxa (Filipova-Marinova et al.). Another methodological study is presented by Bunting and Hjelle, showing that different vegetation sampling techniques effect estimates of relative pollen production, while estimates for relevant source area of pollen are similar for different techniques. The special issue concludes with a contribution by Nielsen and Odgaard, who apply the Landscape Reconstruction Algorithm (Sugita $2007 \mathrm{a}$, b) and explore the results from nine sites across Denmark covering the last 3,000 years.

Open Access This article is distributed under the terms of the Creative Commons Attribution Noncommercial License which permits any noncommercial use, distribution, and reproduction in any medium, provided the original author(s) and source are credited.

\section{References}

Andersen ST (1980) Influence of climatic variation on pollen season severity in wind-pollinated trees and herbs. Grana 19:47-52

Autio J, Hicks S (2004) Annual variations in pollen deposition and meteorological conditions on the fell Aakenustunturi in northern Finland: potential for using fossil pollen as a climate proxy. Grana 43:31-47

Barnekow L, Bragée P, Hammarlund D, Amour NS (2008) Boreal forest dynamics in north-eastern Sweden during the last 10,000 years based on pollen analysis. Veget Hist Archaeobot 17:687-700

Davis MB (2000) Palynology after Y2K-understanding the source area of pollen in sediments. Ann Rev Earth Planet Sci 28:1-18

Fyfe RM, de Beaulieu JL, Binney H, Bradshaw RHW, Brewer S, Le Flao A, Finsinger W, Gaillard MJ, Giesecke T, Gil-Romera G, Grimm EC, Huntley B, Kunes P, Kühl N, Leydet M, Lotter AF, Tarasov PE, Tonkov S (2009) The European pollen database: past efforts and current activities. Veget Hist Archaeobot 18:417-424

Gaillard MJ, Sugita S, Bunting MJ, Middleton R, Broström A, Caseldine C, Giesecke T, Hellman SEV, Hicks S, Hjelle K, Langdon C, Nielsen AB, Poska A, von Stedingk H, Veski S, POLLANDCAL Members (2008) The use of modelling and simulation approach in reconstructing past landscapes from fossil pollen data: a review and results from the POLLANDCAL network. Veget Hist Archaeobot 17:419-443

Gerasimidis A, Panajiotidis S, Athanasiadis N (2008) Five decades of rapid forest spread in the Pieria Mountains (N. Greece) reconstructed by means of high-resolution pollen analysis and aerial photographs. Veget Hist Archaeobot 17:639-652

Giesecke T, Fontana SL (2008) Revisiting pollen accumulation rates from Swedish lake sediments. Holocene 18:293-305

Hicks S (1974) A method of using modern pollen rain values to provide a timescale for pollen diagrams from peat deposits. Memorana Societas Fauna Flora Fennica 49:21-33

Hicks S (1999) The relationship between climate and annual pollen deposition at northern tree-lines. Chemosphere 1:403-416

Hicks S (2001) The use of annual arboreal pollen deposition values for delimiting tree-lines in the landscape and exploring models of pollen dispersal. Rev Palaeobot Palynol 117:1-29

Hicks S, Hyvärinen VP (1986) Sampling modern pollen deposition by means of "Tauber traps": some considerations. Pollen Spores 28:219-242

Huusko A, Hicks S (2009) Conifer pollen abundance provides a proxy for summer temperature: evidence from the latitudinal forest limit in Finland. J Quat Sci 24:522-528

Kuoppamaa M, Goslar T, Hicks S (2009) Pollen accumulation rates as a tool for detecting land-use changes in a sparsely settled boreal forest. Veget Hist Archaeobot 18:205-217

McCarroll D, Jalkanen R, Hicks S, Tuovinen M, Gagen M, Pawellek F, Eckstein D, Schmitt U, Autio J, Heikkinen O (2003) Multiproxy dendroclimatology: a pilot study in northern Finland. Holocene 13:829-838

Poska A, Pidek IA (2010) Pollen dispersal and deposition characteristics of Abies alba, Fagus sylvatica and Pinus sylvestris, Roztocze region (SE Poland). Veget Hist Archaeobot 19:91-101

Räsänen S, Hicks S, Odgaard BV (2004) Pollen deposition in mosses and in a modified 'Tauber trap' from Hailuoto, Finland: what exactly do the mosses record? Rev Palaeobot Palynol 129:103-116

Sjögren P, van der Knaap WO, Huusko A, van Leeuwen JFN (2008) Pollen productivity, dispersal, and correction factors for major tree taxa in the Swiss Alps based on pollen-trap results. Rev Palaeobot Palynol 152:200-210

Sugita $S$ (2007a) Theory of quantitative reconstruction of vegetation I: pollen from large sites REVEALS regional vegetation composition. Holocene 17:229-241

Sugita S (2007b) Theory of quantitative reconstruction of vegetation II: all you need is LOVE. Holocene 17:243-257

Sugita S, Hicks S, Sormunen H (2009) Absolute pollen productivity and pollen-vegetation relationships in northern Finland. J Quat Sci. doi:10.1002/jqs. 1349 